\title{
ДЕФОРМАЦИЯ МОДЕЛИ НАЛОГООБЛОЖЕНИЯ РОССИИ С УЧЕТОМ ВЫЗОВОВ ЦИФРОВОЙ ЭКОНОМИКИ
}

\section{DEFORMATION OF RUSSIAN TAXATION MODEL TAKING INTO ACCOUNT THE CHALLENGES OF THE DIGITAL ECONOMY}

\begin{abstract}
In a changing world, which falls under the influence of two inextricably linked processes in the form of digitization and globalization, the issue of determining the position of the legislator in relation to the choice of the model of legal regulation becomes most relevant. At the same time, despite the active development of digitization processes of both the Russian and world economy, there is no single normative and/or doctrinal concept of cryptocurrency, both in economic science and in jurisprudence. We believe that this problem is of particular relevance in connection with the need to determine the state-power strategy of a public entity with regard to the development of Russian financial and tax legislation, considering current features of the financial system development in the digital age. In this regard, we consider the assessment of the "cryptocurrency" phenomenon taking into account the specifics of the Russian tax-legal regulation as one of the categories of taxation law, which is related to such fundamental notions as "object taxation" and "tax base". Also, the development of the current concept of cryptocurrency significantly affects the most important notions of tax law-fiscal sovereignty, tax residency, legal personality, taxpayers and others. In addition, digitization requires, in
\end{abstract}

the Author's opinion, a revision of theoretical approaches to the system and structure tax law sources.

Keywords: digital economy, tax model, cryptocurrency taxation

Ключевые слова: цифровая экономика, модель налогообложения, налогообложение криптовалют

\section{Введение}

В настоящее время происходит глубокая цифровая трансформация: внедряется новое поколение технологических решений, многие из которых связаны между собой - обработка «больших данных», использование искусственного интеллекта, распределенные вычисления и хранилища данных. Появление виртуальной валюты в относительно недавнем прошлом, ознаменовавшей собой целую «криптоэпоху» в предпринимательской деятельности в целом и юридической в частности, дает возможности для рассуждений на разных площадках относительно возможности и необходимости правового регулирования налоговых последствий отношений, возникающий в связи с использованием виртуальных валют (криптовалют, 
в частности - биткоина), а также сопутствующих им феноменов - майнинга и ICO.

При этом, в соответствии с официальными статистическими сведениями социального опроса, проведенного исследовательским холдингом Ромир, только $44 \%$ опрошенных респондентов в возрасте от 18 лет, проживающих в различных федеральных округах России, имеют какое-то представление о понятии, назначении и особенностях расчетов с использованием криптовалют. При этом большая часть опрошенных (56 \%) не знает, что это такое. Такие термины как «майнинг» и «смарт-контракты» оказались незнакомыми подавляющему большинству российских граждан.

На наш взгляд, логично, что новые технологии должны применяться в правовых рамках, существующих как в виде принципиально новой нормативной базы, так и в традиционных регуляторных сферах. В настоящее время вопросы исследования особенностей налогообложения криптоиндустрии признаны приоритетными в развитии направлений практики работы не только государственных органов, но и организаций, представляющих интересы частных субъектов. Например, в «Пепеляев Групп» организована межотраслевая группа по правовому сопровождению цифровой экономики.

В этой связи логичным считаем отметить и официальную позицию государственных органов, формирующих в итоге правовое поле для владельцев альтернативных платежных средств. Как известно, она является достаточно настороженной и порой содержит не столько сами правила поведения, которые правоприменитель мог бы использовать, находясь в условиях возможности или необходимости использования цифровых валют, сколько суждения, предостерегающие от наступления негативных последствий в виде ответственности, в том числе уголовной, в случае использования криптовалют для финансирования террористической деятельности или совершения иных преступлений, в частности, экономических. Именно такого мнения придерживается Центральный Банк Российской Федерации [Информация Банка России от 04 сентября 2017 г.], возложивший на себя осуществление функций мониторинга рынка криптовалют и выработки подходов к определению и регулированию криптовалют. Так, регулятор финансовых рынков неоднократно подчеркивал, что «процесс выпуска и обращения наиболее распространенных криптовалют полностью децентрализован и отсутствует возможность его регулирования, в том числе со стороны государства. Еще одной из ключевых особенностей использования криптовалют является анонимность пользователей таких криптовалют. Также криптовалюта не требует ведения специальной отчетной документации».

Несмотря на это, профессиональное сообщество проявляет весьма живой интерес к вопросам правового регулирования явлений, возникающих в сфере цифровой экономики. Например, отдельные мысли по вопросу допустимости правового регулирования как самих операций с криптовалютами, так и их последствий (в том числе налоговых) высказывали такие известные специалисты в области налогового права, как Е.В. Кудряшова, И.И. Кучеров, И.А. Хаванова [Кучеров, Хаванова, 2017], И.В. Хаменушко [Хаменушко, 2018], И.А Џинделиани, Л.Д. Шарый и другие.

При этом целесообразным представляется начинать подобные исследования с изучения налогового и финансового законодательства зарубежных стран, имеющих соответствующий позитивный опыт регулирования и правоприменения для определения возможности и/или необходимости заимствований наиболее оптимальных с точки зрения налоговой системы России.

\section{Модели налогообложения стран} Восточной и Центральной Европы с учетом вызовов цифровой экономики

Бесспорным является тот факт, что передовые позиции в установлении налогово-правовых положений в отношении операций с криптовалютой, принадлежат Сингапуру и Японии, поскольку в этих странах не только разработаны модели правового регулирования криптовалютных операций определен правовой статус виртуальных валют, но и реализуется очередная (третья по счету) реформа.

Устанавливая соотношение моделей налогообложения различных стран, необходимо также учитывать, что не выработано единообразного понимания этого словосочетания ни в законодательстве, ни в правоприменительных актах, ни в доктрине налогового права. Нам представляется логичным использовать терминологическое сочетание «модель налогообложения» в двух смыслах - узком (отрасль законодательства, 
регулирующая общественные отношения, связанные с производством и реализацией криптовалют, а также с операциями с ними) и в широком (различные правовые явления, в частности: нормативные акты, правоприменительная практика налоговых и иных государственных органов, особенности структуры и компетенции налоговых органов и других регуляторов). Полагаем, что в любом случае характеристика модели налогообложения должна отражать системообразующие связи налоговых платежей в отдельно взятом регионе, позволяющие принципиально отличить его от иных территорий.

С этих позиций относительно моделей налогообложения криптовалют считаем возможным предложить следующее. Во-первых, сравнение моделей налогообложения

Например, М.С. Поликахин на страницах журнала «Закона.ру» анализирует налоговое регулирование операций с криптовалютами в некоторых зарубежных странах4. Как он указывает, Швейцария всегда славилась уровнем своего банковского сектора и банковской тайной, поэтому не удивительно, что власти этой страны не стали запрещать оборот криптовалют. Она стала неким подобием «налогового рая» для криптовалют. Многие блокчейн стартапы начинали тут и выбрали эту юрисдикцию для организации штаб-квартиры своего бизнеса. Их выбор обусловлен достаточно простым аргументом - в стране криптовалюты освобождены от налогов. Швейцария привлекательна как для ICO, так и для крипто-инвесторов, прежде всего по тому, что законодательно криптовалюта отнесена к деньгам, а не к иностранной валюте. В связи с этим, криптовалюта рассматривается с точки зрения налогообложения как прирост капитала (CGT). Это означает, что применяется только к профессиональным трейдерам. В соответствии с правилами регулирования, инвестирование в ICO признается сбережением.

Дания, в свою очередь, возможно, одна из самых дружественных стран для криптовалюты, имеет весьма привлекательный налог - 0\%. Дания не признает криптовалюты в качестве законного платежного средства, поскольку у них нет «эмитента» и, таким образом, освобождаются от регулирования, как указано в соответствующем документе, опубликованном Национальным банком Дании.

Хотя датское правительство выпустило ряд предупреждений о спекулятивном характере инвестирования в криптовалюты, они, по-видимому, следуют строгому протоколу «hands-off» при криптовалютном регулировании, делегируя регулирующее управление в ЕС. Этот регуляторный вакуум в сочетании с полным отсутствием налоговых помех делает Данию высоко привлекательной страной.

Эстония всегда считалась страной открытой и дружелюбной для любых новых технологий. Поэтому не удивительно что они быстро адоптировали свое законодательство к новым реалиям. Правительство Эстонии анонсировало выпуск собственного токена на базе Ethereum- «Estcoin» и после Венесуэлы это вторая нация, запускающая такой проект. Налоговая политика Эстонии особенно благоприятствует инвестициям в криптовалюту, поскольку они не облагаются налогом на добавленную стоимость. Если стартап хочет попасть в Эстонию, все, что им нужно заплатить, - это обычные бизнес - налоги. ICO не облагаются НДС и подоходными налогами, что делает страну одним из лучших мест для запуска ICO.

В Словении в настоящее время созданы сверхкомфортные условия для физических лиц - индивидуальных инвесторов, для которых доходы от прироста капитала не рассматриваются как совокупная часть дохода и не облагаются налогом. Но юридические лица обязаны платить налог на доходы. Такие правила в Словении существуют с 2013 года. Но есть все основания верить в скорые законодательные изменения. В Словении действует одна из самых больших общественных организаций "Bitcoin Association” выступающая при поддержке гражданского общества.

Словения по праву имеет все шансы стать «Силиконовой долиной Европы». В стране планируется интегрировать блокчейн в стратегию развития информационного общества 2020, признание криптовалюты на бытовом уровне (наличие банкоматов по обмену БТС), авторитетное бизнес сообщество из более чем 300 компаний (включая международные) внедривших и использующих распределенный реестр и блокчейн и т.д. Майнинг в Словенни не облагается НДС.

Германия по праву характеризуется лицами, работающими в сфере криптоиндустрии, как одна из самых благоприятных стран, наряду с Чехией и Эстонией. Германия так же благоприятная страна для индивидуального инвестора или трейдера. Законодательство германии не относит криптовалюты к товарам, сбережениям, или деньгам. Вместо этого, наиболее близко подходит определение - иностранные деньги. 
Торговля криптовалютой рассматривается как частная продажа. В зависимости от условий сделки, доход от продажи криптовалют может подлежать налогообложению. Так доход свыше 600 Евро, полученный от краткосрочных инвестиций, облагается налогом. Но, если инвестиция была долгосрочной (12 месяцев и более), инвестор освобождается от уплаты налогов.

Декрет Президента Республики Беларусь «О развитии цифровой экономики» подписан 22.12.2017 года. Резиденты ПВТ ждали данного документа давно, так как он фактически расширяет правовой режим их деятельности. Однако данный декрет касается не только резидентов ПВТ, так как в нем ведется речь о развитии цифровой экономики в различных аспектах. Так, декрет касается помимо расширения льгот для резидентов ПВТ таких принципиально новых сфер как регулирование криптовалют, криптобирж, ICO, смарт-контрактов, вводя при этом некоторые инструменты, присущие английскому праву.

Вводится возможность для субъектов хозяйствования Республики Беларусь владеть токенами и осуществлять их обращение, в том числе ICO, посредством криптобирж и операторов обмена криптовалют, резидентов Парка высоких технологий. В том числе нет ограничений для владения токенами для юридических лиц с иностранными учредителями.

Немаловажно, что доходы физических лиц и прибыль резидентов ПВТ от обращения токенов, как и доход от майнинга, не будут являться объектами для налогообложения до 2023 года. В том числе введена возможность осуществлять операции на данном рынка за электронные деньги.

Налоговые послабления коснулись также и резидентов ПВТ, нуждающихся в закупке маркетинговых и рекламных услуг у иностранных юридических лиц. Теперь такие платежи освобождаются от НДС, налогов на доходы иностранных лиц и оффшорного сбора. Ранее значительная нагрузка на такие платежи тормозила развитие рынка реализации программного обеспечения через экосистему продажи приложений Apple и Android.

В Декрете предусмотрена возможность использования институтов английского права, которых так не хватало желающим развивать в Беларуси рынок венчурных инвестиций. В первую очередь речь идет о возможности предоставления конвертируемого займа, заключения опционных соглашений с сотрудниками, а также заключения договоров о неконкуренции с бывшими сотрудникам. Ранее данные правовые инструменты

рассматривались либо как противоречащие белорусскому праву, либо как сделки с сомнительной исполнимостью в случае возникновения судебного спора. Такая ситуация фактически вынуждала участников рынка выводить структурирование сделок в зарубежные юрисдикции.

Декретом также разрешено заключение акционерных соглашений, подчиненных иностранному праву, даже в том случае, если участниками хозяйственного общества являются только белорусские лица. Также допустимо установление подсудности разрешения таких споров иностранного суду или международному арбитражу. Данная норма также является беспрецедентной, особенно в части установления подсудности и введения возможной арбитрабельности спора.

Либерализация коснулась и миграционного законодательства. Иностранным инвесторам и IT специалистам разрешено пребывать в Беларуси без визы до 180 дней. Также резидентам ПВТ для найма иностранных сотрудников не будет необходимости получать специальное разрешение на работу в Беларусь через органы внутренних дел.

Декрет Президента Республики Беларусь «О развитии цифровой экономики» можно назвать первым в своем роде достаточно революционным нормативно-правовым актом, регулирующим развитие криптоэкономики в государстве. Какова будет практика применения данного Декрета, особенно в части применения белорусскими судами элементов английского права? На данный вопрос ответ может дать только правоприменительная практика, которая только начинает формироваться на наших с вами глазах.

Как мы видим, на «криптовалютный климат» внутри государства влияет совокупность факторов: географических, социально-культурных, экономических, политических и других. При этом даже при наличии единых правил правового регулирования для стран Евросоюза по ряду ключевых экономических вопросов, каждое государство по-разному оценивает криптовалюту и устанавливает свои условия налогово-правового регулирования операций с ней. В связи с эти считаем принципиально важным отметить, что вопросы правового регулирования весьма актуальны в общемировом масштабе. 


\section{Налогообложение операций}

\section{с криптовалютами в России на}

\section{современном этапе}

Исчисление налога на добавленную стоимость (далее - НДС) при совершении криптовалтных операций.

Для целей налогообложения НДС биткоин предлагается рассматривать в качестве товара или услуги, пользуясь ст. 38 НК РФ, где содержится определение соответствующих понятий для целей налогообложения. В мае 2017 г. зампредседателя Банка России О.Н. Скоробогатова предложила облагать налогами операции с криптовалютами (с учетом особенностей, которые найдут отражение в законопроекте) исходя из их квалификации как «цифрового товара». Чуть позднее Председатель ЦБ РФ Э.С. Набиуллина охарактеризовала биткоин, в том числе для целей косвенного налогообложения, как digital asset («цифровой актив»).

Как известно, не признается объектом обложения НДС осуществление операций, связанных с обращением российской или иностранной валюты, за исключением целей нумизматики (п. 3 ст. 39, п. 2 ст. 146 НК РФ). Схожий подход может быть применен и к реализации биткоина.

Однако виртуальные валюты имеют такую особенность, как анонимность их владельцев, что может означать, что стандартные подходы к раскрытию схем ухода от налогообложения могут стать неэффективными. Это потребует адекватного правового регулирования вопроса принципиальной возможности раскрытия сведений о владельцах криптовалют, а также объемов таких сведений для целей обращения к ним национальных налоговых органов. В конечном итоге подлежит оценке, стоит ли устанавливать правила налогообложения для криптовалют, если нет уверенности в том, что суммы аккумулированных налогов будут больше тех средств, которые придется потратить на администрирование соответствующих платежей.

В этой связи целесообразно также подумать о «пороговых» значениях сумм криптовалют, находящихся в собственности того или иного субъекта, при превышении которых налогообложение вообще есть смысл реализовывать, а при недостижении подобных «пороговых» значений есть смысл предусмотреть освобождение от налогообложения. Кроме того, при правовом регулировании налогообложения операций за биткоины нужно учитывать наличие или отсутствие предпринимательского характера такой деятельности.

При решении сопутствующих налоговым вопросам особенности организации бухгалтерского учета и отчетности при осуществлении криптовалютных сделок, основными вопросами, которые в ближайшем будущем предстоит попутно решить законодателю это правила вычета расходов, а также трудоемкость их подтверждения.

С точки зрения бухгалтерского учета, непосредственно связанного с исчислением НДС, не предусмотрено специального счета для учета криптовалюты, причем ни в российской, ни в общемировой практике. Теоретически можно предположить, что могут быть рассмотрены варианты учета криптовалюты на счете 04 «Нематериальные активы» или счете 55 «Специальные счета в банках», предусмотренные РСБУ.

Исчисление налога на доходы физических лиц (далее - НДФЛ) при совершении криптовалтных операций.

Минфин России в своих письмах и разъяснениях избегает каких-либо конкретных выводов, сообщая, что особый порядок налогообложения операций с криптовалютой главой 23 НК РФ не предусмотрен. В связи с эти Минфин России указывает на необходимость при исчислении НДФЛ по операциям с криптовалютой налогоплательщикам необходимо руководствоваться общими положениями НК РФ. Чуть более обширное толкование появилось относительно недавно и связано с налогообложением НДФЛ сделок по продаже криптовалюты. Так, Минфин России фактически признает, что п. 17.1 ст. 217 НК РФ к таким операциям не применяется, поскольку освобождается от налогообложения доход от продажи движимое имущество, если лицо владеет им более трех лет. Также не подлежит применению пп. 1 п. 2 ст. 220 НК РФ об имущественном вычет для доходов от продажи имущества, если лицо владеет им более трех лет. Соответственно, подобные доходы невозможно уменьшить на сумму, не превышающую 250 тысяч рублей. Исходя из формулировок анализируемого документа, доходы от продажи биткойнов разрешается уменьшать на документально подтвержденные расходы от их же приобретения. На наш взгляд, это означает возможность для правоприменителя, производящего реализационные сделки с криптовалютой, учесть доходы, связанные с ее продажей. 
Об исчислении налога на прибыль организаций по операциям с криптовалютой.

Позиция Минфина России по вопросу исчисления налога на прибыль по операциям с криптовалютой также единообразна. Министерство рекомендует при исчислении налога на прибыль по операциям с криптовалютой (в том числе по операциям майнинга) руководствоваться главой 25 НК РФ, отмечая, что особый порядок при операциях с криптовалютой положениями главы 25 НК РФ не предусмотрен.

\section{Библиография}

Информация Банка России от 04 сентября 2017 г. «Об использовании частных «виртуальных валют» (криптовалют)».

Kucherov I.I., Khavanova I.A. (2017), Налоговые последствия использования альтернативных платежных средств (теоретико-правовые аспекты) (Тах consequences of the use of alternative means of payment (theoretical and legal aspects)), „Вестник Пермского Университета. Юридические науки/ Bulletin of Perm University. Jurisprudence" no. 1.

Khamenushko I.V. (2018), Операции с криптовалютами: возможные модели налогообложения (Operations with cryptocurrencies: possible tax models), „Предпринимательское право/ Business Law” no. 1.

\section{Author biography}

Olga Lutova - Candidate of Legal Sciences, Associate Professor at the Department of Administrative and Financial Law, Nizhny Novgorod State University named after N.I. Lobachevsky (Nizhny Novgorod, Russia), legal adviser at the Federal State Budgetary Institution "State Institute of Medicines and Good Practice" (Moscow, Russia); head of the grant of the Russian Foundation for Basic Research "Study and justification of the choice of a tax model in the era of digital transformation"; author of more than 50 publications on tax law and 1 monograph. 